\title{
INFLUENCE OF ORGANIZATIONAL CULTURE, TEAM CONDUCTIVITY, PERSONALITY, AND TRUST TO THE OUTLET LEADING ORGANIZATION COMMITMENT
}

\author{
Dedi Sutan Ardani \\ Bank Negara Indonesia \\ dedi.ardani@bni.co.id
}

\begin{abstract}
The purpose of this study was to Determine the effect of organizational culture, cohevision team, persoanlity, and trust of organizational commitment outlet leader in Bank Negara Indonesia, Regional offices, Senayan Jakarta. This research tried to answer problems about the organizational comitment with increasing evidence of service employee. The research was conducted on organizational commitment involving of 98 outlet leader had been selected from a target Populations of 130 outlet leader by using the quantitative approach with path analysis methods. The research of hypothesis testing show: (1) organizational culture had a direct positive effect on organizational commitment; (2) personality had a direct positive effect on organizational commitment; (3) trust had a direct positive effect on organizational commitment; (4) organizational culture had a direct positive effect on trust: (5) cohevision team had a direct positive effect on trust: (6) personality had a direct positive effect on trust: (7) organizational culture had a direct positive effect on cohevision team (8) personality had a direct positive effect on cohevision team: Therefore to improve the organizational commitment of outlet leader in Bank Negara Indonesia, Regional Offices Senayan Jakarta. Need to increase is organizational culture, cohevision team, personality and trust.
\end{abstract}

Keywords: Organzational Culture, Cohevision Team, Personality, Trust, OrganizationalCommitment.

As the first bank owned by the Government of Indonesia, PT Bank Negara Indonesia (Persero) Tbk established in 1946 started its history by performing its function as a central bank as stipulated in Government Regulation in Lieu of Law no. 2/1946. When viewed from the performance of 130 Outlet BNI in the area of Jakarta Regional Office Senayan, it is seen that the average performance of outlet is still far from expected, then this fact informs that the competence of Outlet Leaders owned BNI Jakarta Senayan Regional Office has not shown maximum performance or not have Strong organizational commitment to BNI's performance.

Based on the observations made by researchers found some things that indicate the lack of organizational commitment Outlet BNI Outlet Jakarta Regional Office Senayan. First, it relates to the inability of Outlet Leaders to motivate their team members, so that team members are enthusiasticless in performing their duties and there is unbelieveable in the Outlet Leader's capability. Second, Outlet Leaders do not have a business strategy or business plan in executing their business, so that activities are not appropriate or even away from the vision and mission of BNI. Third, Outlet Leaders are still working according to their KPI / Job Description or are still working on the comfort zone, working just to abort their KPI without having the desire or initiative to make innovations for business development and Improve business process. Fourthly, there are Outlet Leaders who do not want to improve their competence, such as continuing education to higher level, motivational training and seminars, this is necessary considering the increased responsibility and job demands of Outlet Leader.Head of Business Banking BNI Manado Region Julius Aritonang said Hermita's performance is not just a leader but able to build solidity with subordinates so that achievement for achievement can be achieved by BNI Manado area, which has been considered 'small' territory compared to other BNI region. This illustrates that the organization's commitment to outlet leaders is very important in 
the banking world and the progress of a company. Therefore interested in conducting research related to organizational commitment of PT leaders. BNI Senayan Regional Office.

Under these conditions, it can be formulated research problem: Is there a direct influence of organizational culture on organizational commitment? Is there a direct influence of personality on organizational commitment? Whether there is a direct effect of trust on organizational commitment? Is there a direct influence of organizational culture on trust? Is there a direct influence on the confidence the team cohesiveness? Is there a direct influence of personality on trust? Is there a direct influence of organizational culture on team cohesiveness? Is there a direct influence of personality on team cohesiveness?

Timothy T. Baldwin (2013: 243) defines the organizational commitment as follows, "organizational commitment is an attitude representing the extent to which an employee identifies with his organization and desires to remain a member of the organization". Organizational commitment is an attitude that reflects the extent to which an employee identifies with the organization and the desire to remain an organization member. Organizational commitment of employees can be seen from the attitude of loyalty to the workplace.

Jenifer M. George, and Gareth R. Jones (2013: 528) define the organizational culture as follows, "organizational culture is the set of shared values, beliefs and norms that influences the way employees think, feel and behave toward people outside the organization".Organizational culture is a shared set of values, beliefs and norms that affect the way employees think, feel and behave towards people outside the organization. Organizational culture needs to be developed in accordance with the development of the organization's environmental needs. The development of organization on the creation of achievemet culture, the type of culture that encourages and appreciates the performance of employees.Cohesiveness is about the unification of forces. Most scholars seek the concept of cohesiveness, back to the theories of Kurt Lewin, Leon Festinger, and their colleagues inResearch Center of Group Dynamics. Lewin, In 1943, used the term cohesive to describe a force that keeps the group intact by keeping it.

The unity of its members. Festinger defines cohesiveness as the total of a force that belongs to the group members who persist in the group. John R. Schermerhorn Jr., (2014: 502) defines the following cohesiveness, "cohesiveness is the degree to which members are attracted to and motivated to remain part of a team". Compactness is the extent to which members are interested and motivated to remain part of the team. In a group in needed motivation to complement each other and continue to be part of a group that has been agreed with.

We all have different personalities. When we speak of a person's personality, we do not mean that the person has charisma or is constantly smiling. As an organizational behavioralist, we are explaining a dynamic concept of the growth and development of one's personality. Personality is the whole way an individual reacts and interacts with other individuals. Personality is most often described in terms of measurable properties indicated by a person. Ricky W. Grifin, and Gregory Moorhead (2014: 66) define the personality as follows, "personality is the relatively stable set of psychological attributes that distinguish one person from another". Personality is a relatively stable set of psychological attributes that distinguishes one from another. Defines the personality we use most often formulated by Gordon Allport around 70 Years ago.

Trust is defined as a measure of how many employees want information, to work with each other and not to take advantage of others. Trust is the most sensitive issue in international organizations and businesses. Jason A. Colquitt, et.al (2015: 204) defines, "Trust is defined as the willingness to be authorized by an authority on the positive expectations of the authority's actions and intentions." Trust as a willingness to accept criticism of authority based on positive expectations about orotiritas and intentions. 


\section{METHOD}

The population is all leaders of PT outlets. BNI. The sampling technique used is simple random sampling with the assumption that the population has the same relative characteristics (homogeneous). Research conducted in Indonesia. This research uses quantitative approach with survey method. Its population 130 leaders outlet PT. BNI. The samples were 98 randomly picked drivers. Data collection using questionnaires and analyzed by path analysis.

\section{RESULT}

The structural equation formed on the first sub-structure model formed by the path coefficient of the variables $\mathrm{X} 1$ to $\mathrm{Y}, \mathrm{X} 3$ to $\mathrm{Y}$, and the path coefficient of the $\mathrm{X} 4$ to $\mathrm{Y}$ variables are: $\mathrm{Y}$ $=$ py $1 \mathrm{X} 1+$ py $3 \mathrm{X} 3+$ py $4 \mathrm{X} 4+$ py 1 . With large $(\mathrm{Ry} .134) 2=0.3815$ so py $\varepsilon 1=0.786$. So form

The structural equation on the first sub-structure model: $\mathrm{Y}=0.269 \mathrm{X} 1+0.276 \mathrm{X} 3+0.298 \mathrm{X} 4+0.786$.

The structural equation formed on the second sub-structural model formed by the path coefficient of the variables $\mathrm{X} 1$ to $\mathrm{X} 4, \mathrm{X} 2$ to $\mathrm{X} 4$, and the path coefficients of the $\mathrm{X} 3$ to $\mathrm{X} 4$ variables are: $\mathrm{X} 4=\mathrm{p} 41 \mathrm{X} 1+\mathrm{p} 42 \mathrm{X} 2+\mathrm{p} 43 \mathrm{X} 3+\mathrm{p} 4 \varepsilon 2$. With large $(\mathrm{R} 4.123) 2=0.2650$ so $\mathrm{p} 4 \varepsilon 2=0.857$. Thus the form of structural equation in the second sub-structural model: $\mathrm{X} 4=0.233 \mathrm{X} 1+0.244 \mathrm{X} 2+$ $0.255 \times 3+0.857$.

The structural equation formed on the third sub-structural model formed by the path coefficient of the variables $\mathrm{X} 1$ to $\mathrm{X} 2$ and $\mathrm{X} 3$ to $\mathrm{X} 2$ is: $\mathrm{X} 2=\mathrm{p} 21 \mathrm{X} 1+\mathrm{p} 23 \mathrm{X} 3+\mathrm{p} 2 \varepsilon 3$. With large (R2.13) $2=0.1194$ so $\mathrm{p} 2 \varepsilon 3=0.938$. Thus the form of structural equation in the third sub-structure model: $\mathrm{X} 2=0.221 \mathrm{X} 1+0.227 \mathrm{X} 3+0.938$.

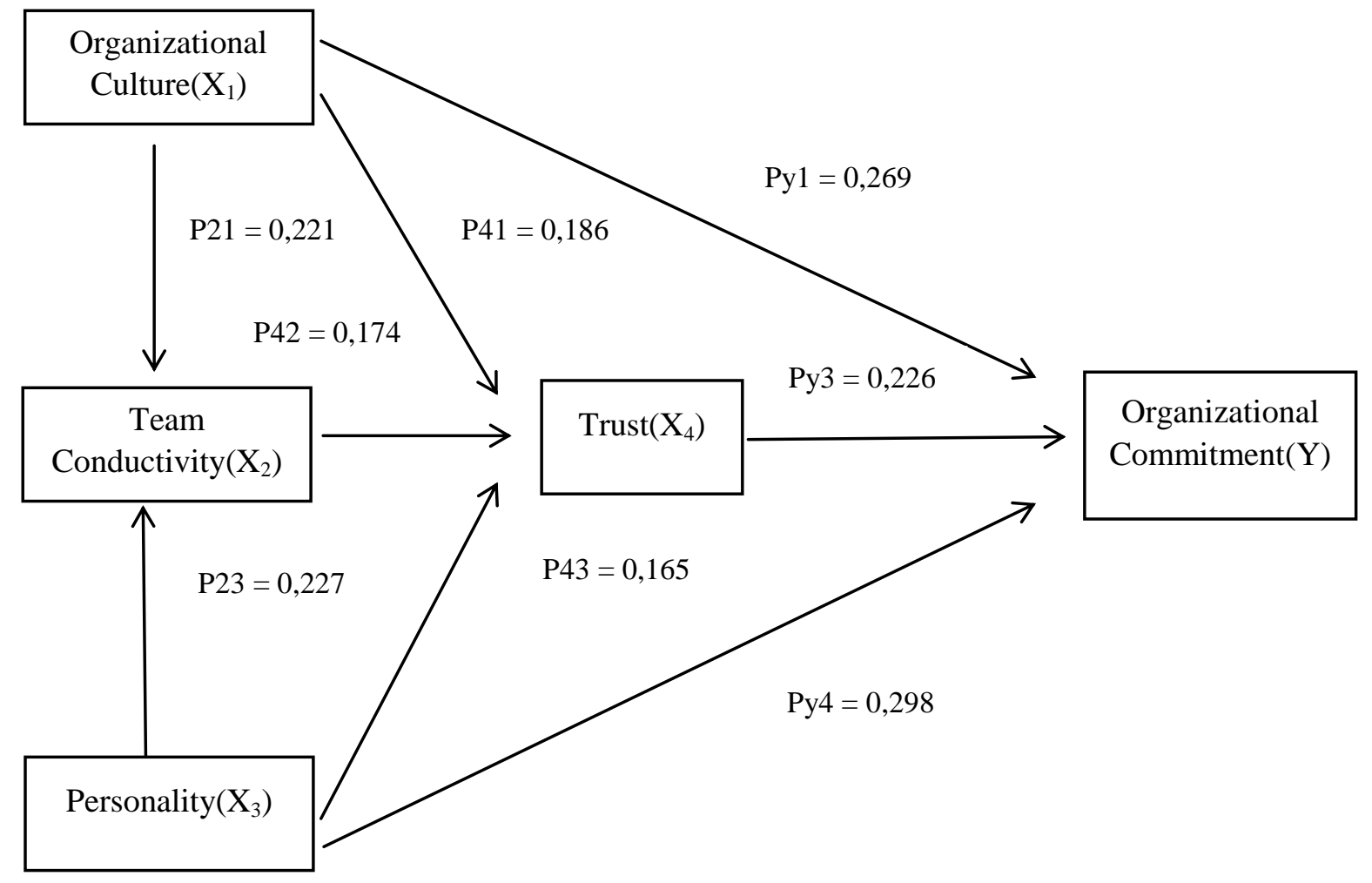

The results of the path coefficient calculation can be seen in the following table.

Table 1.Instant Influence Between Variables 


\begin{tabular}{|c|c|c|c|c|c|c|}
\hline \multirow{2}{*}{ No. } & Direct influence & \multirow{2}{*}{ Path Coefficient } & $\mathbf{d}$ & \multirow{2}{*}{$\mathbf{t}_{\text {hitung }}$} & \multicolumn{2}{|c|}{$\mathbf{t}_{\text {tabel }}$} \\
\cline { 5 - 7 } & & & & & $\boldsymbol{\alpha}=\mathbf{0 , 0 5}$ & $\boldsymbol{\alpha}=\mathbf{0 , 0 1}$ \\
\hline 1. & $\mathrm{X}_{1}$ to $\mathrm{Y}$ & 0,269 & 94 & $3,12 * *$ & 1,99 & 2,63 \\
\hline 2. & $\mathrm{X}_{3}$ to $\mathrm{Y}$ & 0,298 & 94 & $3,28 * *$ & 1,99 & 2,63 \\
\hline 3. & $\mathrm{X}_{4}$ to $\mathrm{Y}$ & 0,233 & 94 & $2,54 *$ & 1,99 & 2,63 \\
\hline 4. & $\mathrm{X}_{1}$ to $\mathrm{X}_{4}$ & 0,244 & 94 & $2,60 *$ & 1,99 & 2,63 \\
\hline 5. & $\mathrm{X}_{2}$ to $\mathrm{X}_{4}$ & 0,255 & 94 & $2,77 * *$ & 1,99 & 2,63 \\
\hline 6. & $\mathrm{X}_{3}$ to $\mathrm{X}_{4}$ & 0,221 & 95 & $2,25 *$ & 1,99 & 2,63 \\
\hline 7. & $\mathrm{X}_{1}$ to $\mathrm{X}_{2}$ & 0,227 & 95 & $2,32 *$ & 1,99 & 2,63 \\
\hline 8. & $\mathrm{X}_{3}$ to $\mathrm{X}_{2}$ & & & & & \\
\hline
\end{tabular}

Keterangan :

$* \quad=\operatorname{signifikan}\left(\mathrm{t}_{\text {hitung }}>\mathrm{t}_{\text {tabel }}\right.$ pada $\left.\alpha=0,05\right)$

** $\quad=$ sangat signifikan $\left(t_{\text {hitung }}>t_{\text {tabel }}\right.$ pada $\left.\alpha=0,01\right)$

The results of this study indicate (1) organizational learning has a direct positive effect on the effectiveness of work. (2) compensation has a direct positive effect on work effectiveness. (3) work attachment has a direct positive effect on work effectiveness. (4) organizational learning has a direct positive effect on job attachment (5) competence has positive direct effect on work attachment. (6) the compensation has a positive direct effect on the employment attachment.

\section{DISCUSSION}

Based on the results of research conducted proposed discussion ofresearch as follows:

First, The results of the first hypothesis analysis resulted in the finding that organizational culture had a positive direct effect on organizational commitment. Based on these findings, it can be concluded that organizational commitment is directly influenced by positive organizational culture. Increased organizational culture will lead to increased organizational commitment. The results of this study are consistent with the opinion of some experts including Jason A. Colquitt et.al (2015: 552) said,"this view assumes that the organization has a strong culture and definite norms and values that is wants employees to adopt, which is not always the case. Some organizations don't have strong culture that they want employees to adapt to, or they might be trying to change their culture and want new employees to come in and shake things up". This view assumes that organizational culture at the Bank.

BNI 46 has a strong influence through the norms, values that will be adopted by every employees. There are very few Banks with strong organizational culture. In the majority in some organizations they are constantly striving to update existing cultures with the aim that the culture can be accepted in all circles. Bank BNI believes that employees are one of the most valuable assets for the organization or company. Sustainability would not be possible without the contribution of the employee. BNI also tried to create conditions and the best work for all employees. BNI wants every employee to feel proud to be a part of the BNI family and can work and incise achievements together.

Second, The results of the second hypothesis analysis resulted in the finding that personality had a positive direct effect on organizational commitment. Based on these findings, it can be concluded that organizational commitment is directly influenced by positive personality. Increased personality will lead to increased organizational commitment. The results of this study is consistent with the opinion of some experts including Steven L. McShane and Mary Ann Von Glinow (2010: 112) said,"organizational commitment refers to the employee's emotional attachment to, 
identification with, and involvement a particular in organization". Organizational commitment is an emotional identification of bank employees BNI 46 involvement with Bank BNI 46, personality is the whole way BNI 46 employees react and interact with other employees. Personality most often Described in terms of measurable properties shown by employees of Bank BNI 46. We all have different personalities. When we talk about the personalities of Bank BNI 46 employees, we do not mean that the person has charisma or is constantly smiling. As an organizational behavioral expert, we are explaining a dynamic concept of the growth and development of personalities of employees of Bank BNI 46.

Third, The results of the third hypothesis analysis resulted in the finding that trust had a positive direct effect on organizational commitment. Based on the findings, it can be concluded that organizational commitment is directly influenced by trust. Increased trust will lead to increased organizational commitment. The results of this study are consistent with the opinions of some experts including Jason A. Colquitt, et.al (2015: 241) said trust can be interpreted as a will based on positive expectations about the actions of authority and intent. When we believe, we become willing to put ourselves out there. Furthermore Jason A. Colquitt et.al says:"trust has a strong positive effect on commitment. Employees who are willing to be vulnerable to authorities tent to have higher levels of affective commitment and higher levels of normative commitment. Trust has no effect on continuance commitment". Trust has a strong positive effect on organizational commitment of employees. Employees who are willing to be vulnerable to the authorities to have higher levels of affective commitment and higher levels of normative commitment.

Trust between the two can be created by, among others, provide timely and sufficient resources for employees in completing the work, providing adequate training for employment needs, respecting differences of opinion and differences in the success achieved by the employee. Therefore, trust is the main capital for leaders in an effort to increase organizational commitment of employees to the organizations in which they work.

Fourth, The results of the fourth hypothesis analysis provide findings that organizational culture has a direct positive effect on trust. Thus it can be concluded that trust is directly affected positively by organizational culture. Increased organizational culture will lead to increased trust. Organizational culture is a shared set of values, beliefs and norms that affect the way employees think, feel and behave toward people outside the organization. Organizational culture needs to be developed in accordance with the development of the organization's environmental needs. The development of the organization should be directed towards the creation of an achievemet culture, a type of culture that encourages and rewards the performance of employees of Bank BNI 46. According to Atikson (2010: 739) organizational culture as reflection the underlying assumptions about how the work is done: what is acceptable and can not be Accepted and what behaviors and actions are driven and desperate, a more detailed definition is, "the collection of traditions, values, policies, beliefs and attitudes that constitute a pervasive context for everything we do and think in an organization".

Collection of traditions, values, policies, beliefs and attitudes that are the broad context for everything we do and think in an organization. Trust can arise from the culture created within the organization, as a result of the interaction of members with other members of the organization. Furthermore John R. Schermerhorn (2013: 246) says, "organizational culture this as the system of shared belief and values that shapes and guides the behavior of its members". Organizational culture is a system of beliefs and shared values that form and guide the behavior of its members. It could be said that trust can be influenced from environmental organizations in their work and confidence is the result of their interaction with other colleagues in carrying out the work. Bank BNI realizes that maintaining the best talents in the company is a very important strategy. To maintain potential human beings. BNI continues to improve and innovate in employee retention programs. 
Fifth , The results of the fifth hypothesis analysis resulted in the finding that team cohesiveness had a direct positive effect on trust. Based on these findings it can be concluded that trust is directly affected positively by team cohesiveness. Increased team cohesiveness will lead to increased confidence. Trust as a willingness to accept criticism of authority based on positive expectations about authority and intent and Cohesiveness is the extent to which members are interested and motivated to remain part of the team. Same as expressed by StevenL. Mcshane, dan Von Glionv (2010:252) said; "a high level of trust occurs when others affect you in situations where you are at risk but you believe they will not harm you. Trust includes both your beliefs and conscious feelings about the relationship with other team members. In other words, person both logically evaluates the situation as trustworthy and feels that it is trustworthy. Trust can also be understood in terms of the foundation of the trust. From this perspective, people trust others on the basis of three foundations: calculus, knowledge, and identification". High confidence can affect employees of Bank BNI 46 in any situation and believe that they will not harm, trust includes conscious and conscious feelings about relationships with other team members. In other words, a good person logically evaluates the situation as trustworthy and feels that it can be trusted. Trust can also be understood in terms of the basis of trust. From this perspective, other believers are on the basis of three foundations: calculus, knowledge, and identification. In cohesiveness is essential for trust, while compactness is the extent to which the loyal employees and commitment to the group. In a very compact team, members work together well, support and trust each other and are generally effective to achieve their chosen goals.

Sixth,The results of the sixth hypothesis analysis resulted in the finding that personality had a direct positive effect on trust. Based on the findings it can be concluded that trust is directly affected positively by the personality. Increased personality will lead to increased trust. Personality can be defined as the characteristics of a relatively immortal individual and disposition.

Which form the pattern of distinguishing one person from another. Suzanne C. de Janasz, Karen O. Dowd, and Beth Z. Schneider (2012: 8) says: "personality describe the relatively stable of characteristic, tendencies, and temperaments that have a been formed by heredity and by social, cultural and environmental factors". Personality describes the relatively stable characteristics, tendencies, and temperaments that are shaped by heredity and social, cultural and environmental factors, where within a culture there is a belief that is implanted among members with each other. Jason A. Colquiit et.al (2015: 278) said, "personality refers to the structure and propensities inside people that explain their characteristic patterns of thought, emotion and behavior". Personality refers to structures and trends in society that explain their characteristic patterns of thinking, emotion and behavior. The personalities of employees of Bank BNI 46 can reflect the level of confidence in the work or the environment around them work. And Personality also incorporates a set of physical and mental characteristics that reflect how employees of Bank BNI 46 see, think, act and feel in carrying out all their activities in the organization or company where they work, therefore a good personality should be instilled and spread to all members In order to arise trust between fellow members of the organization in melakasanakan work and achieve together the goals of the organization.

Seventh, The results of the seventh hypothesis analysis provide findings that organizational culture has a direct positive effect oncohesivenessteam. Based on these findings it can be concluded that team cohesiveness is directly affected positively by organizational culture. Increased organizational culture will lead to an increase in team cohesiveness. Every individual has the potential to engage in social relationships at various levels of relationships, from ordinary intercourse to interdependence. Intimacy and interdependence in dealing with and addressing everyday needs. Individuals will not be able to meet the needs of his life without any relationship with the social environment, therefore individuals need to build a satisfying interpersonal relationship. Participation in the process of relationships can fluctuate along the dependent (independent) and independent 
(independent) range, meaning that an individual's time depends on the other person and someday the other person depends on the individual. According to Gareth R. Jones (2013: 201), "organizational culture as the set of shared values and norms that control organizational members interactions with each other and with suppliers customers and other people outside the organization". Organizational culture as a set of values and norms that control member organizations interaction with each other together and with supplier customers and others outside the organization.

Eight,The results of the eighth hypothesis analysis resulted in the finding that personality has a direct positive effect on team cohesiveness. Based on the findings, it can be concluded that team cohesiveness.

Directlyinfluenced positively by personality. Increased personality will lead to an increase in team cohesiveness. The results of this study are consistent with the opinion of some experts including Sapna Aeron, Suman Pathak (2012) with his research"Personality, Cohesion and Performance" explain, "it is clear that group performance is affected by group cohesiveness and personality. The differential influence of personality versus cohesion should be investigated. Given the research support, it is very important to realize and create awareness, about combination of personality of group members and group cohesiveness particularly in organizational setups who tend to employ work groups and work teams expecting high results. It is widely recognized that teams are important to organizational effectiveness, and the number of organizations using teams is increasing, but little is known about the relationship between team composition variables as personality and cohesion and its influence on team effectiveness in actual work settings". The results of this study explain that the performance of the organization can be influenced by the cohesiveness of the group and the personalities of each employee. This is evident from the combination of personality combined with the compactness of the group members in the work can affect the performance of the employees in work. Efforts to increase the fitting in the performance of employees is to consider the personality of the employee and the employee to combine into a solid and compact team in their duties. A solid team willbe easy to reach targets that have been specified.

\section{CONCLUSION}

Based on these results it presented the following conclusions: (1) direct effect positive organizational culture to organizational commitment. (2) personality has a positive direct effect on organizational commitment (3) trust has a direct positive effect on organizational commitment. (4) The direct effect positive organizational culture of trust. (5) Team cohesiveness positive direct effect on confidence. (6) the personality of a positive direct effect on confidence. (7) organizational culture has a direct positive effect on the cohesiveness of TEAM. (8) personality has a direct positive effect on the cohesiveness of TEAM.

\section{REFERENCES}

Baldwin, Timothy T., William H. Bommer, Robert S. Rubbin. (2013). Managing Organizational Behavior What Great Managers Know \& Do Second Edition. New York: Mc Graw Hill.

Bateman. Thomas S., Scoot A. Snell. (2015).Managemenet Leading \& Collaborating in a Competitive World 11 edition. New York:McGraw-Hill.

Cassiy. Carlene M., Robert Kreitner. (2011).Principles of Management 12 Edition. Asia:SouthWestern Cengange Learning.

Colquitt, Jason A. Jeffry A. LePine, Michael J Wesson. (2015).Organizational Behavior: Improving Performance and Commitment in the Worplace 4 edition. New York: McGraw-Hill, Companies, Inc.

De Janasz, Suzanne C., Karen O. Dowd, Beth Z. Schneider. (2012).Interpersonal Skill in Organization 14 edition. New Yok: McGraw Hill.

George, Jennifer M Gareth Jones. (2014).Contemprary Management Global Edtition. New York: Mc Graw Hill. 
George, Jennifer M. Gareth R. Jones. (2012).Understanding and Managing Oganization Behavior, Sixth Edition. New Jersey:Pearson Prantice Hall.

Gibson, James L., John M. Ivancevich,James H. Donnelly, Jr, Robert Konopaske. (2012).Organizations Behavior, Structure, Processes 14 edition.New York:McGrwa-Hill.

Gomez-Mejia. Luix R., David B. Balkin. (2012).Management People Perfromance Change. New Jersey: Pearson.

Greenberg, Jerald. (2011).Behavior in organizations 10 edition. England: Pearson.

Greenberg, Jerald. Robert A. Baron. (2008).Behavior in Organization 9 edition. New Jersey: Pearsin Prentice Hall.

Griffin, Ricky W., Gregory Moorhead. (2014).Organizational Behavior: Managing People and Organizations, Eleventh Edition. South-Western: Cengange Learning.

Griffin, Ricky W. (2013).Management Principles and Practices 11 Edition. New York:McGrawHill.

Heneman III, Herbert G. Timothy A. Judge, John Kammeyer Mueller. (2015).Staffing Organizations Sedition. New York: McGraw Hill.

Hitt, Michael A., J. Stewart Black. Lyman W. Porter. (2012).Management 3 Edition. New Jersey: Pearson.

Ivancevich. John M., Robert Konopakse, Michael T. Matteson. (2014).Organizational behavior \& Management 10 Edition. New YorK: McGraw Hill.

Jones, Gareth R. (2013).Organizational Theory, Design and Change 7 Edition. England:Pearson.

Kinicki, Angelo, Brian Williams. (2011).Management a Practical Introduction. New York: McGraw Hill.

Kinicki, Angelo, Robert Kreitner. (2011).Organizational Behavior 9 Edition. New York, McGraw Hill.

Kreitner, Robert. (2009).Management 11 Edition. Canada:Hought Mifflin Harcourt publishing company.

Luthans, Fred. (2011).Organization Behavior An Evidence-Based Approach 12 Edition. New York:McGraw-Hill.

McShane, Steven L. Mary Ann Von Glinov. (2010).Organizational Emerging Knowledge and Pactice for The Real World. New York: McGraw Hill.

McShane, Steven. Mara Olekalns, Tony Travaglione. (2013).Organizational Behavior Emerging Knowledge. Global Insight 4 edition. Asia: McGraw Hill.

Mullins, Laurie J. (2005).Management And Organisational Behavior, Seventh Edition. London: Prentice Hall.

Newstroom, John W. (2015).Organizational Behavior Human Behavior At Work 14 edition. New York: McGraw-Hill.

Newstroom. John W., Keith Davis. (1997).Organizational Behavior Human Behavior at Work 10 Edition. New York:McGraw-Hill.

Quick, James Campbell, Debra L. Nelson. (2013). Principles Of Organizational Behavior Realities And Challenges 8 Edition. USA: South Western Cengange Learning.

Robbins, Stephen P, Mary Coulter. (2014).Managemnet 12 edition. New York: McGraw Hill.

Robbins, Stephen P., Timothy A. Judge. (2015).Organizational Behavior 16 edition. England: Pearson.

Schemerhorn, John R., JR, Richard N. Osborn, Mary Uhl-Bien, James G. Hunt. (2012).Organizational Behavior 12 edition. Asia: Wiley.

Schermerhon, John R. (2013).Introduction to Management 12 edition. Asia; Wiley.

Schermerhorn, John R. Jr,Daniel G. Bachrach. (2015).Introduction to Management 13 edition. USA:Wiley.

Schermerhorn. John R. Jr, Paul Davidson, David Poole, Peter Woods, Alan Simon, Ellen McBaron. (2014).Management 5 edition. Australia: Wiley.

Slocum, John W., Don Hellriegel. (2011).Principles of Organizational Behavior 13 edition. China: South-Western.

Vecchio, Robert P. (2006).Organizational Behavior: Core Concept,6th Edition. Ohio: Thompson Corporation.

Walker, Anthony. (2011). Organizational Behavior in Contsruction. UK:Wiley BlackWell. 
InternationalJournal of Human Capital Management, Vol. 1 (2), December2017 